\title{
PROFIL KEMAMPUAN BERPIKIR KRITIS SISWA DALAM MENYELESAIKAN SOAL HIGHER ORDER THINKING SKILLS (HOTS) DITINJAU DARI JENIS KELAMIN
}

\author{
Tri Putih Lestari \\ Pendidikan Matematika, Fakultas Matematika dan Ilmu Pengetahuan Alam, Universitas Negeri Surabaya \\ e-mail: trilestari16030174069@mhs.unesa.ac.id \\ Pradnyo Wijayanti
}

Pendidikan Matematika, Fakultas Matematika dan Ilmu Pengetahuan Alam, Universitas Negeri Surabaya

e-mail: pradnyowijayanti@unesa.ac.id

\begin{abstract}
Abstrak
Kemampuan berpikir kritis merupakan proses berpikir individu secara sistematis, logis, dan objektif dalam mengelola informasi, menemukan solusi, serta mengevaluasi suatu permasalahan yang diperoleh berdasarkan enam kriteria, berikut (1)Focus (Fokus), (2)Reason (Alasan), (3)Inference (Menyimpulkan), (4)Situation (Situasi), (5)Clarity (Kejelasan) dan (6)Overview (Tinjauan Kembali). Dalam mencapai kemampuan berpikir kritis dapat penerapan soal HOTS. Penelitian ini merupakan penelitian deskriptif dengan pendekatan kualitatif yang bertujuan untuk mendeskripsikan kemampuan berpikir kritis siswa dalam menyelesaikan soal matematika HOTS ditinjau dari jenis kelamin. Instrumen yang digunakan dalam penelitian ini adalah tes kemampuan matematika dan soal matematika HOTS. Subjek yang digunakan dalam penelitian ini terdiri dari dua siswa SMP, satu siswa laki-laki dan satu siswa perempuan dengan kemampuan matematika yang tinggi. Hasil penelitian kemampuan berpikir kritis siswa laki-laki dan siswa perempuan dalam menyelesaikan soal matematika HOTS menunjukan bahwa siswa mampu memahami dan menemukan inti permasalahan, dapat memberikan alasan yang mendukung cara yang siswa gunakan, serta dapat menarik kesimpulan dengan menggunakan cara yang telah siswa tentukan. Namun hanya siswa perempuan yang dapat mengungkapkan faktor penting yang mendukung cara yang digunakan, serta dapat menjelesakan istilah pada setiap langkah penyelesaiannya.
\end{abstract}

Kata Kunci: Bepikir Kritis, Higher Order Thinkig Skills

Abstract

Critical thinking skills are are individual thought processes systematically, logically, and objectively in managing information, finding solutions, and evaluating the problems obtained based on six criteria, as follows (1) Focus, (2) Reason, (3) Inference, (4) Situation, (5) Clarity and (6) Overview. In achieving critical thinking skills, you can apply HOTS questions. This research is a descriptive study with a qualitative approach that aims to describe students' critical thinking skills in solving HOTS math problems in terms of gender. The instruments used in this study were a math ability test and HOTS math problems. The subjects used in this study consisted of two junior high school students, one male student and one female student with high math ability. The results of the research on male and female students' critical thinking skills in solving HOTS math problems show that students are able to understand and find the core of the problem, can provide reasons that support the way students use, and can draw conclusions using the method students have specified. However, only female students can reveal important factors that support the method used, and can explain the term at every step of its completion.

Keywords: Critical Thinking, Higher Order Thinking Skill

\section{PENDAHULUAN}

Pada kurikulum 2013 memuat pembelajaran 4C yang meliputi: (1) Critical Thinking (kemampuan berpikir kritis), (2) Creativity : mendorong siswa untuk berpikir kreatif dalam menemukan ragam solusi, merancang strategi baru atau menemukan cara-cara yang tidak lazim digunakan sebelumnya, (3) Collaboration (kerja sama), dan (4) Communication (kemampuan komunikasi) (Widana, 2019).
Salah satu kemampuan yang akan digunakan dalam membantu memahami suatu permasalahan yakni kemampuan berpikir kritis (critical thinking). Menurut Gerhand berpikir kritis merupakan suatu proses kompleks yang melibatkan penerimaan dan pengasaan data, analisis data, evaluasi data dan mempertimbangkan aspek kualitas dan kuantitas serta membuat seleksi atau membuat keputusan berdasarkan hasil evaluasi (Suwarma, 2009). Menurut John Dewey berpikir kritis secara esensial sebagai sebuah proses aktif, dimana seseorang berpikir segala hal secara mendalam, mengajukan berbagai 
pertanyaan, menemukan informasi yang relevan daripada menunggu informasi secara pasif (Ariyana,2018). Jadi, kemampuan berpikir kritis merupakan kemampuan berpikir individu dalam mengolah informasi, menemukan solusi, serta mengevaluasi dari permasalahan yang diperoleh.

Ennis mengemukakan enam kriteria berpikir kritis, yaitu : (1) Focus (Fokus), merupakan langkah awal dari berpikir kritis di dalam memahami inti permasalahan, (2) Reason (Alasan), berarti dapat memberikan alasan untuk jawaban atau simpulan dalam menyelesaikan permasalahan yang diberikan, (3) Inference (Menyimpulkan), berarti menilai kualitas kesimpulan dengan asumsi alasannya dapat diterima, dalam langkah ini proses penarikan kesimpulan yang dilakukan dapat diterima dan beralasan, (4) Situasion (Situasi) yakni memahami serta mengungkapkan faktor penting yang perlu dipertimbagkan dalam menemukan solusi yang tepat dari suatu permasalahan yang diberikan, (5) Clarity (Kejelasan), berarti menjelaskan istilah yang digunakan dalam menyelesaikan persoalan, sehingga tidak menimbulkan kesalahan dalam membuat kesimpulan, dan (6) Overview (Tinjauan kembali), berarti memeriksa kembali kebenaran jawaban secara menyeluruh yang telah diambil.

Dalam membantu mengasah kemampuan berpikir kritis dalam sebuah pembelajaran dapat menggunakan jenis soal higher order thinking skills (HOTS). Keterampilan tersebut dapat mendorong siswa untuk berpikir lebih luas dan mendalam tentang materi yang dipelajarinya, karena pada keterampilan tersebut siswa harus menerapkan konsep-konsep yang terkait dengan materi yang dipelajari serta dapat mendorong siswa untuk menuangkan segala ide-ide kreatif dalam menemukan solusi.. Menurut King (2011:1) "higher order thinking skills include critical, logical, reflective, metacognitive, and creative thinking". Keterampilan berpikir tingkat tinggi dapat didefinisikan didalamnya termasuk kemampuan berpikir kritis, logis, reflekti, metakognisi, dan kreatif. Menurut Anderson \& Krathwohl dalam diskusi tingkat pemrosesan kognitif yang lebih tinggi melibatkan dimensi proses kognitif analisis, evaluasi, dan mencipta (Anderson \& Krathwohl, 2001). Jadi, dapat disimpulkan bahwa Higher Order Thinking Skills adalah keterampilan berpikir dalam menyelesaikan permasalahan non algoritmik, kompleks, dan kemungkinan memiliki banyak solusi dan pada proses berpikir seseorang tidak menggunakan keterampilan memanggil pada setiap solusinya serta dapat mengukur keterampilan menganalisis, mengevaluasi dan mencipta. Berdasarkan uraian di atas soal matematika HOTS dapat menguji keterampilan menganalisis, mengevaluasi dan mencipta, keterampilan tersebut berada di tiga tingkatan teratas Taksonomi Bloom.

Hasil dari studi Internasional Programme for Internasional Assesment (PISA) menunjukkan prestasi literasi membaca (reading literacy), literasi matematika (mathematic literacy), dan literasi sains (scientify literacy) yang dicatat siswa Indonesia sangat rendah yakni pada tahun 2018 menduduki peringkat 73 dari 78 negara yang terdaftar dalam studi Internasional tersebut (OECD,2018). Sehubungan dengan hal tersebut siswa Indonesia yang masih rendah dalam kemampuan berpikir tingkat tinggi serta kemampuan berpikir kritis yang masih kurang karena siswa di Indonesia masih sering menggunakan kemampuan mengingat, memahami serta mengaplikasikan dalam memecahkan suatu masalah. Sedangkan pada pembelajaran saat ini siswa di tuntut harus memiliki kemampuan berpikir tingkat tinggi, salah satunya kemampuan yang digunakan yaitu kemampuan berpikir kritis dalam menyelesaikan suatu permasalahan. Salah satu jenis soal yang dapat mencapai kemampuan berpikir kritis siswa yakni soal Higher Order Thinking Skills (HOTS) (Ariyana, 2018).

Pada setiap jenjang pendidikan formal, peserta didik terdiri atas dua jenis kelamin yakni laki-laki dan perempuan. Perbedaan jenis kelamin tersebut memunculkan kemungkinan bahwa proses berpikir kritis dalam menyelesaikan masalah akan menemukan proses yang berbeda. Hal tersebut dapat dilihat pada penelitian yang dilakukan oleh Krisagotama, dkk (2015) menyatakan bahwa kemampuan berpikir kritis siswa laki-laki cenderung tidak dapat memahami soal dengan baik, sehingga kesulitan dalam informasi yang penting dalam permasalah tersebut namun dapat menentukan hal yang ditanya dengan tepat. Sedangkan berpikir kritis siswa perempuan dapat memahami maksud soal dengan baik dan siswa dapat menentukkan hal yang diketahui dan ditanyakan dengan tepat. Berkaitan dengan hal tersebut, jenis kelamin siswa dapat mempengaruhi dalam mengelola informasi, menemukan solusi serta mengevaluasi dari setiap permasalahan yang diberikan. kemampuan yang dimiliki oleh siswa laki-laki dan siswa perempuan sangatlah berbeda, salah satunya dalam menggunakan kemampuan berpikir kritis untuk menyelesaikan suatu permasalahan.

Penelitian ini selaras dengan penelitian yang dilakukan oleh Krisagotama, dkk (2015) yang berjudul "Profil Berpikir Kritis Siswa Kelas VII MTs Negeri Jember 1 Filial dalam Menyelesaikan Soal Operasi Hitung Bilangan Pecahan Berdasarkan Gender". Persamaan penelitian yang dilakukan oleh Krisagotama, dkk(2015) dengan penlitian ini adalah mendeskripsikan kemampuan berpikir kritis yang ditinjau dari jenis kelamin, namun terdapat perbedaan antara penelitian ini adalah dalam 
penelitian ini mendeskripsikan kemampuan berpikir kritis dalam menyelesaikan soal matematika HOTS sedangkan penelitian yang dilakukan Krisagotama, dkk(2015) adalah mendeskripsikan kemampaun berpikir kritis siswa dalam menyelesaikan soal operasi hitung bilangan pecahan. Penelitian ini juga selasar dengan penelitian yang dilakukan oleh Fridanianti, dkk (2018) yang berjudul "Analisis Kemampuan Berpikir Kritis Dalam Menyelesaikan Soal Aljabar Kelas VII SMP Negeri 2 Pangkah Ditinjau dari Gaya Kognitif Reflektif dan Kognitif Implusif'. Persamaan penelitian yang dilakukan oleh Fridanianti,dkk (2018) dengan penelian ini adalah mendeskripsikan kemampuan berpikir kritis siswa dalam menyelesaikan soal matematika. Adapun juga perbedaan yang dilakukan oleh Frisdinianti, dkk(2018) adalah dalam penelitian tersebut peninjau subjek yang digunakan dalam penelitian yaitu gaya kognitif reflektif dan implusif, sedangkan dalam penelitian ini peninjau subjek berdasarkan jenis kelamin. Berdasarkan uraian diatas peneliti tertarik untuk melakukan penelitian dengan judul "Profil Berpikir Kritis Siswa dalam Menyelesaikan Soal Matematika HOTS Ditinjau dari Jenis Kelamin”. Tujuan dari penelitian ini yakni untuk mendeskripsikan profil kemampuan berpikir kritis siswa laki-laki dan siswa perempuan dalam menyelesaikan soal matematika HOTS.

\section{METODE}

Penelitian ini bertujuan untuk mendeskripsikan profil kemampuan berpikir kritis siswa dalam menyelesaikan soal higher order thinking skills (HOTS) ditinjau dari jenis kelamin. Berdasarkan tujuan tersebut, penelitian ini termasuk penelitian deskriptif dengan pendekatan kualitatif. Subjek dalam penelitian ini adalah dua siswa SMP kelas VIII yang terdiri dari satu siswa laki-laki dan satu siswa perempuan.

Instrumen yang digunakan dalam penelitian ini terdiri dari instrument utama dan instrument pendukung. Instrument utama yakni peneliti itu sendiri dan instrument pendukung yaitu tes kemampuan matematika, soal HOTS matematika dengan materi bilangan dan aljbar serta pedoman wawancara. Tes kemampuan matematika digunakan untuk memilih subjek dengan kemampuan matematika tinggi. Subjek yang terpilih menyelesaikan permasalahan yang tertera pada instrumen soal HOTS untuk mengetahui atau melihat kemampuan berpikir kritis siswa dalam menyelesaikan permasalahan yang diberikan. Soal HOTS yang digunakan terdiri dari 3 soal dengan materi yang telah diperlajari yakni materi bilangan dan aljabar. Kemudian setelah menyelesaikan permasalahan tersebut dapat dilanjutkan dengan wawancara. Tujuan wawancara untuk mendapat informasi yang lebih lengkap mengenai kemampuan berpikir kritis subjek dalam menyelesaikan soal HOTS yang diberikan, sehingga informasi yang tidak tertulis dapat diketahui. Analisis data yang digunakan dalam peneliian ini yaitu analisis hasil tes kemampuan matematika dan analisis kemampuan berpikir kritis siswa dalam menyelesaikan soal HOTS. Tes kemampuan matematika dianalisis secara kuantitatif dan hasil tes ditulis dalam skala 0-100. Kemampuan berpikir kritis siswa dapat dianalisis dengan menggunakan indikator kemampuan berpikir kritis. Peneliti menggunakan indikator yang dikemukakan oleh Ariyana(2018) yang dikemas seperti berikut.

Tabel 1. Indikator Kemampuan Berpikir Kritis Siswa dalam Menyelesaikan Soal matematika HOTS

\begin{tabular}{|c|c|c|}
\hline No. & Kriteria & Indikator Berpikir Kritis \\
\hline 1. & Foct & \begin{tabular}{ll}
\multicolumn{2}{c}{ Memahami dan menuliskan } \\
inti permasalahan yang \\
dimaksud pada soal yang \\
diberikan
\end{tabular} \\
\hline 2. & Reason (Ala & $\begin{array}{lrr}\begin{array}{l}\text { Memberikan } \\
\text { mendukung }\end{array} & \text { alasan } & \text { yang } \\
\text { menggunakan } & \text { cara } & \text { yang } \\
\text { dipilih untuk } & \text { menyelesaikan } \\
\text { soal. } & & \end{array}$ \\
\hline 3. & $\begin{array}{l}\text { Infe } \\
\text { (M }\end{array}$ & $\begin{array}{l}\text { Proses penarikan kesimpulan } \\
\text { yang dapat diterima, yaitu } \\
\text { mengikuti langkah-langkah } \\
\text { yang telah dipilih dalam } \\
\text { menemukan kesimpulan. }\end{array}$ \\
\hline 4. & $\begin{array}{l}\text { Situatio } \\
\text { (Situasi }\end{array}$ & \begin{tabular}{lr} 
Mengungkapkan & faktor \\
penting yang perlu \\
dipertimbangkan, yakni \\
menghubungkan suatu konsep \\
\multicolumn{2}{l}{ dalam menyelesaikan soal. }
\end{tabular} \\
\hline 5. & $\begin{array}{l}\text { Clarity } \\
\text { (Kejelasan }\end{array}$ & $\begin{array}{l}\text { Menjelaskan istilah yang } \\
\text { berkaitan dengan cara yang } \\
\text { digunakan } \\
\text { menyelesaikan soal. }\end{array}$ \\
\hline 6. & $\begin{array}{l}\text { Overview } \\
\text { (Tinjauan } \\
\text { Kembali) }\end{array}$ & $\begin{array}{l}\text { Memeriksa } \\
\text { penyelesaiannya } \\
\text { menyeluruh. }\end{array}$ \\
\hline
\end{tabular}

Berikut cuplikan salah satu soal matematika HOTS yang digunakan dalam penelitian ini.

Pak Bayu mempunyai kebun apel berbentuk persegi dan Pak Dani mempunyai kebun jeruk berbentuk persegi panjang. Ukuran kebun Pak Dani $25 m$ lebih dari panjang sisi kebun apel Pak Bayu. Sedangkan lebarnya 15m lebih dari panjang sisi kebun apel Pak Bayu. Jika diketahui perbandingan luas kebun apel Pak Bayu dengan luas kebun jeruk Pak Dani adalah 2:3 dan jumlah luas kebun mereka adalah $25000 \mathrm{~m}^{2}$. Tentukan keliling masing-masing kebun tersebut!

\section{HASIL DAN PEMBAHASAN}

Pengambilan data yang dilakukan peneliti dimulai dari memberikan tes pertama yaitu tes kemampuan matematika yang bertujuan untuk mengelompokkan siswa berdasarkan kemampuan matematika. Pada pengelompokkan tersebut 
yang dipilih sebagai subjek yaitu siswa yang memiliki kemampuan matematika tingkat tinggi. Berdasarkan pengelompokkan tersebut, 2 subjek yang terpilih terdiri dari 1 siswa laki-laki dan 1 siswa perempuan. 2 subjek tersebut melakukan tes selanjutnya untuk dapat dideskripsikan kemampuan berpikir kritis pada soal HOTS pada penelitian ini. Setelah menyelesaiakan soal HOTS, peneliti melakukan wawancara yang bertujuan untuk mengetahui informasi lebih lengkap mengenai kemampuan berpikir kritis pada setiap subjek.

Profil Kemampuan Berpikir Kritis Siswa Laki-Laki (SL) dalam Menyelesaikan Soal Higher Order Thinking Skills

Berikut hasil dan pembahasan kemampuan berpikir kritis siswa laki-laki dalam menyelesaikan soal HOTS. Pada Nomor 1 SL dapat memahami permasalahan tersebut sehingga dapat menentukan inti permasalahan dari soal tersebut. SL dapat memahami inti permasalahan dengan mudah yaitu membaca permasalahan tersebut dan informasi penting yang menurut ia penting dan inti permasalahan pada soal yaitu membandingkan skor Cindy dan Desy pada sebuah kompetisi dan menentukan yang lolos pada tahap penyisihan tersebut.

Pada soal tersebut, SL dapat memberikan alasan yang mendukung ia memilih cara untuk menentukan penyelesaian pada permasalahan tersebut. Alasan yang diberikan SL saat ia memilih cara yang digunakan dalam menyelesaikan permasalahan tersebut ialah cara yang ia pilih sudah sesuai dan yang mudah dipahami oleh SL untuk mencari solusi sesuai dengan permasalahan.

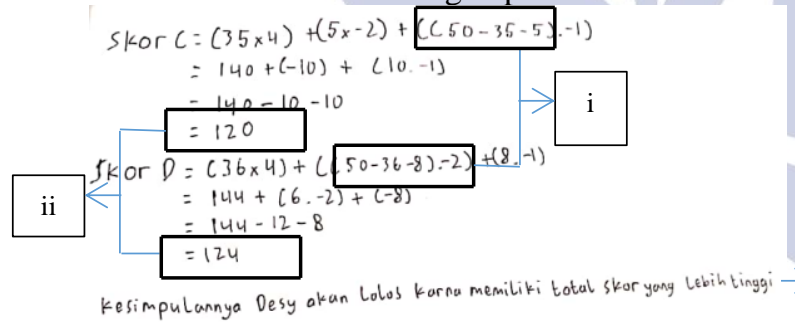

Gambar 1. Proses Penarikan Kesimpulan Soal Nomor 1

Pada proses penarikan kesimpulan SL mengikuti langkah-langkah yang telah ia tentukan sebelumnya. Langkah-langkah yang dilakukan SL yaitu ia mencari berapa soal yang tidak dikerjakan Cindy dan berapa soal salah yang dikerjakan Desy, hal ini dapat dilihat pada Gambar 1 nomor (i). Kemudian SL mencari skor Cindy dan Desy dengan menggunakan operasi hitung bilangan sehingga skor Cindy dan Desy diperoleh. SL menemukan skor yang diperoleh Cindy yaitu 120 poin dan Desy 124 poin, hal tersebut juga tertera pada Gambar 1 nomor (ii). Gambar 1 nomor (iii) merupakan penarikan kesimpulan yang dilakukan SL setelah mengikuti cara yang ia pilih sebelumnya. Berdasarkan uraian tersebut SL dapat melakukan penarikan kesimpulan yang sesuai dengan langkah-langkah yang ia pilih sebelumnya.

Pada indikator berpikir kritis situation (situasi), SL dapat mengungkapkan faktor penting yang mendukung ia menyelesaikan permasalahan tersebut. Faktor penting tersebut dapat dilihat pada Gambar 1 nomor (i), pada gambar tersebut salah satu faktor yang penting untuk SL gunakan untuk mencari solusi. Selain itu, SL juga menghubungkan konsep bilangan sesuai dengan informasi yang ia temukan dalam soal.

Pada indikator berpikir kritis clarity (kejelasan) SL dapat menjelaskan istilah yang ia gunakan dalam penyelesaiannya dan dapat menjelesakan setiap langkah yang ia lakukan. SL menjelaskan langkah awal yang ia lakukan pada saat menyelesaikan soal tersebut yakni mencari banyaknya soal tidak dikerjakan oleh Cindy dan banyaknya soal salah yang dikerjakan oleh Desy, setelah ia menemukan poin tersebut SL mencari masin-masing skor total Cindy maupun Desy. Langkah terakhir, SL membandingkan kedua skor untuk mencari sebuah kesimpulan yang sesuai dengan permasalahan.

Pada indikator overview (tinjauan kembali), SL tidak melakukan tahapan peninjauan kembali terhadap penyelesaian yang telah ia lakukan. SL merasa yang ia kerjakan sudah benar, sehingga ia tidak melakukan tinjauan kembali terhadap penyelesaian tersebut.

Pada Nomor 2 SL memahami permasalahan dengan melihat gambar pada soal, sehingga ia menemukan inti permasalahan tersebut. Pada soal tersebut SL mengungkapkan bahwa inti permasalahan soal Nomor 2 yaitu menentukan keliling setiap lahan. Berdasarkan hal tersebut SL mampu memahami dan menemukan inti permasalaahan dengan melihar gambar yang tersedia pada soal.

SL mengungkapkan alasan yang mendukung ia memilih cara untuk menyelesaikan soal tersebut berdasarkan gambar yang tertera pada soal sehingga ia memutuskan cara yang ia pilih. SL juga mengungkapkan memilih cara tersebut berdasarkan ia memahami dan menemukan inti permasalahan pada soal tersebut.

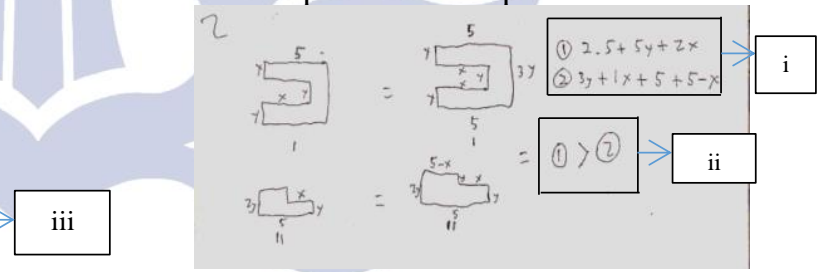

Gambar 2. Proses Penarikan Kesimpulan Nomor 2

Gambar 2 pada nomor (i) menunjukkan proses penyelesaian SL sesuai dengan cara yang ia pilih. SL melakukan operasi penjumlahan aljabar pada penyelesaian Nomor 2. Operasi penjumlahan yang dilakukan sesuai dengan ukuran yang ada pada gambar soal. Pada Gambar 2 nomor (ii) menunjukkan penarikan kesimpulan setelah SL melakukan langkah-langkah yang sesuai dengan cara yang ia pilih untuk menyelesaiakan permasalahan tersebut.

Pada indikator situation (situasi), SL tidak mengungkapkan faktor penting yang perlu dipertimbangkan untuk menyelesaikan soal tersebut. Faktor penting yang berkaitan dengan soal tersebut yakni penggunaan konsep aljabar dengan luas bangun datar, selain itu untuk mempermudah mencari luas setiap lahan pada soal tersebut yakni membagi lahan tersebut menjadi lahan yang lebih kecil. Faktor-faktor penting yang dapat mempermudah SL untuk mencari solusi yang sesuai dengan permasalahan tersebut tidak ia ungkapkan. Hal tersebut dapat dilihat pada Gambar 2, SL tidak 
mengungkapkan faktor penting untuk dipertimbangkan dalam menyelesaikan soal tersebut.

Pada indikator clarity (kejelasan), SL tidak dapat menjelesakan istilah yang berkaitan dengan penyelesaian yang ia gunakan dalam mencari solusi untuk permasalahan tersebut. SL juga tidak meninjau kembali penyelesaian yang telah ia lakukan, sehingga SL menarik kesimpulan tidak sesuai dengan inti permasalahan pada soal tersebut. Dari uraian diatas, kemampuan berpikir kritis SL dalam menyelesaikan soal Nomor 2 yaitu mampu memahami dan menemukan inti permasalahan, memberikan alasan yang mendukung ia memilih cara yang sesuai, serta melakukan penarikan yang sesuai dengan cara yang ia pilih.

SL memahami soal Nomor 3 dengan cara membaca soal secara berulang sampai menemukan inti permasalahan yang ada pada soal tersebut. SL dapat menemukan inti permasalahan untuk Nomor 3 yaitu mencari keliling lahan milik Pak Bayu dan Pak Dani jika yang diketahui perbandingan luas mereka. SL memahami permasalahan pada Nomor 3 dengan membaca soal tersebut dengan berulang-ulang sampai ia menemukan inti permasalahan yang ada pada soal tersebut.

SL dapat memberikan alasan yang mendukung dalam menggunakan cara ia pilih untuk menyelesaiakan soal tersebut. Alasan yang diberikan SL berdasarkan informasi yang tertera pada soal tersebut. Pada soal terdapat perbandingan luas kebun milik Pak Bayu dan Pak Dani, sehingga SL menggunakan cara perbandingan terlebih dahulu untuk mencari panjang sisi kebun Pak Bayu. Setelah SL mencari panjang sisi kebun Pak Bayu, SL mencari keliling kebun masing-masing. Dari uraian tersebut SL mengungkapkan alasan yang mendukung ia memilih cara untuk menyelesaikan soal tersebut berdasarkan inti permasalahan.

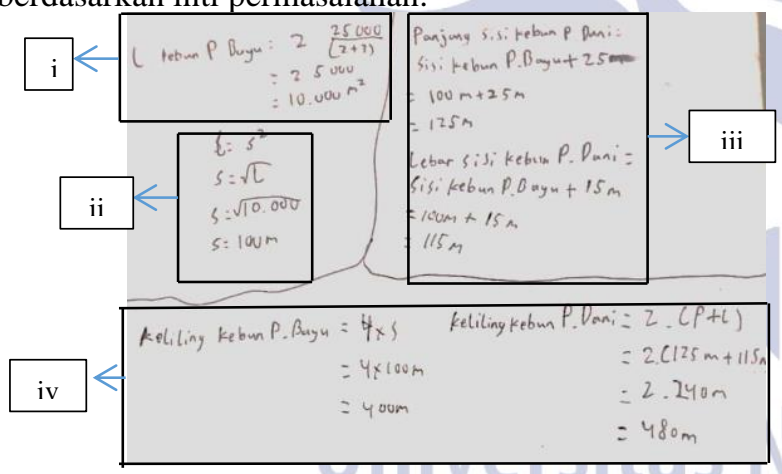

Gambar 3. Proses Penarikan Kesimpulan Nomor 3

Pada penarikan kesimpulan SL mengikuti langkah-langkah sesuai dengan cara yang sudah ia pilih untuk menyelesaikan soal Nomor 3. Gambar 3 nomor (i) SL mencari luas kebun Pak Bayu dari rasio perbandingan luas kebun Pak Bayu dan Pak Dani. Setelah menemukan luas kebun Pak Bayu SL mencari panjang sisi kebun Pak Bayu yang dapat dilihat pada Gambar 3 nomor (ii). Setelah mencari panjang sisi kebun Pak Bayu, SL mencari ukuran kebun Pak Dani. Ukuran panjang kebun Pak Dani adalah 25 meter lebih dari panjang sisi kebun Pak Bayu sehingga panjang kebun Pak Dani adalah 125 meter, ukuran lebar kebun Pak Dani 15 meter lebih dari panjang sisi kebun Pak Bayu sehingga ukuran lebar kebun Pak Dani adalah 115 meter. Hal tersebut dapat dilihat pada Gambar 3 nomor (iii). Setelah mencari panjang sisi kebun Pak Bayu dan mencari ukuran panjang dan lebar kebun Pak Dani, SL mencari keliling kebun mereka. Setiap langkah yang dilakukan SL menuju penarikan kesimpulan yang sesuai dengan permasalahan tersebut. Berdasarkan uraian tersebut SL dapat menarik kesimpulan sesuai dengan cara yang ia pilih sebelumnya..

Pada indikator berpikir kritis situation (situasi), SL dapat mengungkapkan faktor penting yang mendukung penyelesaian soal tersebut. Pada Gambar 3 dapat terlihat faktor-faktor tersebut diungkapkan dan digunakan untuk membantu SL mencari solusi. Faktor penting yang ada pada nomor tersebut yaitu penggunaan antara materi perbandingan, operasi hitung bilangan, luas dan keliling bangun datar.

Pada indikator berpikir kritis clarity (kejelasan), SL dapat menjelesakan istilah yang berkaitan dengan penyelesaian yang telah ia lakukan. SL juga dapat menjelaskan setiap langkah penyelesaian yang ia lakukan pada soal tersebut. SL menjelaskan langkah yang ia lakukan untuk menyelesaikan soal tersebut, langkah awal setelah SL memahami dan menemukan inti permasalahan ia mencari panjang sisi kebun Pak Bayu dari rasio perbandingan luas kebun mereka, kemudian ia mencari panjang dan lebar kebun Pak Dani sehingga SL dapat mencari keliling kebun mereka. Dari uraian tersebut SL dapat menjelaskan istilah yang ia gunakan dalam penyelesaian soal Nomor 3.

Pada indikator overview (tinjauan kembali) SL tidak melakukan tahapan peninjauan kembali solusi yang ia berikan untuk permasalahan ini. Dari uraian kemampuan berpikir kritis SL pada Nomor 3, SL dapat memahami dan menemukan inti permasalahan, dapat memberikan alasan yang mendukung, membuat kesimpulan yang sesuai dengan cara yang ia pilih, mengungkapkan inti permasalahan yang mendukung penyelesaiannya, serta dapat menjelesakan istilah yang berkaitan dengan penyelesaiannya.

Berdasarkan uraian diatas, kemampuan berpikir kritis SL dalam menyelesaiakan soal matematika HOTS yaitu SL dapat memahami dan menemukan inti permasalahan, dapat memberikan alasan yang mendukung ia memilih cara, serta dapat membuat kesimpulan yang sesuai dengan cara yang ia pilih. Hal tersebut sejalan dengan penelitian yang dilakukan oleh Kaliky (2018) yang mengatakan bahwa siswa laki-laki mampu merumuskan pokok permasalahan, mampu memilih argumen yang logis sehingga dapat memberikan alasan yang sesuai dengan langkah yang dipilih, serta mampu memberikan kesimpulan berdasarkan cara yang dipilih sebelumnya.

\section{Profil Kemampuan Berpikir Kritis Siswa Perempuan (SP) dalam Menyelesaikan Soal Higher Order Thinking Skills}

Berikut hasil dan pembahasan kemampuan berpikir kritis siswa perempuan dalam menyelesaikan soal HOTS. 


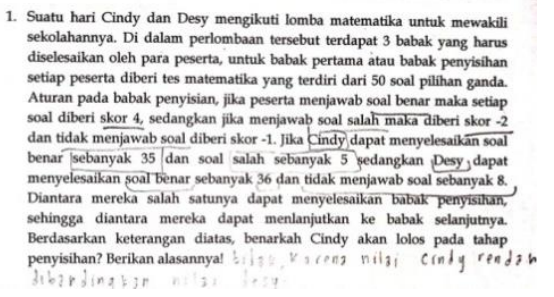

Gambar 4. Hasil SP Memahami Inti Permasalahan

Pada gambar tersebut menunjukkan bahwa SP dapat memahami dan menemukan inti permasalahan dari soal tersebut. Pada soal Nomor 1 SP memahami dengan cara membaca permasalahan dengan cermat serta SP menggarisbawahi dan membuat kotak kecil yang menjelaskan bahwa hal-hal tersebut merupakan kata kunci yang dapat membantu ia mencari solusi yang sesuai dengan inti permasalahan tersebut. Inti permasalahan dari soal tersebut yaitu mencari perbedaan nilai pada kompetisi Cindy dan Desy.

Pada indikator reason (alasan) untuk SP dapat mengungkapkan alasan yang mendukung ia memilih cara untuk menyelesaikan soal tersebut ialah berdasarkan inti permasalahan yang ia temukan dan ia hanya memikirkan cara tersebut yang sesuai dengan permasalahan Nomor 1.

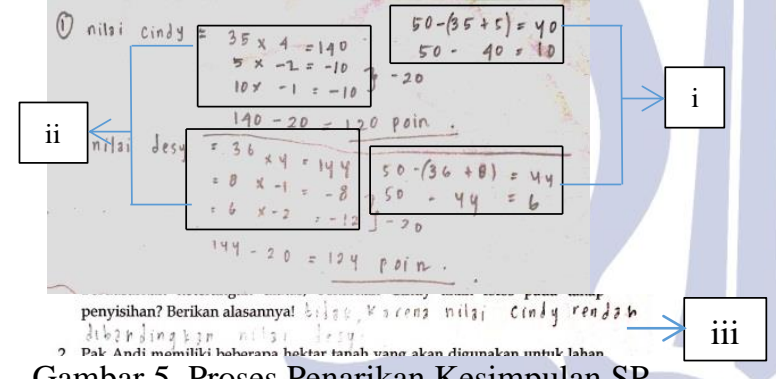

Gambar 5. Proses Penarikan Kesimpulan SP

Gambar diatas merupakan proses penarikan kesimpulan dengan mengikut langkah-langkah yang ia pilih untuk soal Nomor 1. Pada gambar tersebut SP dapat menuliskan secara rinci pada setiap langkah penyelesaiannya. SP memilih cara mengoperasikan setiap kata kunci yang telah ia tandai. Langkah awal yang ia lakukan adalah mencari berapa soal yang tidak dikerjakan soal Cindy dan berapa soal salah yang dikerjakan salah oleh Desy, hal itu dapat dilihat pada Gambar 5 nomor (i). Kemudian mencari setiap skor yang didapatkan oleh Cindy dan Desy dengan cara mengoperasikan soal yang dapat mereka kerjakan dengan benar, salah, dan tidak dikerjakan dengan skor setiap soal yang telah ditentukan , hal itu dapat dilihat pada Gambar 5 nomor (ii) Gambar 5 nomor (iii) menunjukkan SP melakukan penarikan kesimpulan dengan mengikuti cara yang ia pilih. Dari hasil uraian gambar, SP dapat menarik kesimpulan dengan mengikuti cara yang telah ia pilih untuk mencari solusi pada soal tersebut.

Pada indikator situation (situasi), SP menjelaskan bahwa faktor yang mendukung dalam menyelesaikan soal Nomor 1 adalah mencari nilai dari setiap soal benar, salah, dan tidak dikerjakan oleh Cindy maupun Desy. Pada soal tersebut SP menghubungkan dengan materi operasi bilangan bulat, hal tersebut dapat dilihat pada Gambar 5 yang dapat menjelaskan operasi bilangan bulat yang digunakan dalam mencari solusi. Dari hasil uraian diatas, dapat disimpulkan bahwa SP pada indikator situation (situasi) dapat mengungkapkan faktor penting yang berhubungan dengan langkah-langkah yang ia pilih sebelumnya.

Setelah mengungkapkan faktor penting pada soal Nomor 1 SP dapat menjelaskan istilah yang berkaitan dengan setiap langkah dari penyelesaian yang ia lakukan. SP menjelaskan bahwa pada permasalahan tersebut membandingkan nilai Cindy dan Desy di sebuah kompetisi. SP juga dapat menjelaskan setiap langkah yang ia lakukan untuk menyelesaikan soal tersebut. Hal tersebut dapat terlihat dari hasil uraian pada indikator inference dan situation, SP dapat menjelaskan dengan setiap langkah penyelesaian yang ia lakukan.

Pada indikator overview (tinjauan kembali), SP tidak melakukan pemerikasaan kembali penyelesaian yang ia kerjakan. Namun secara keseluruhan penyelesaian yang dikerjakan oleh SP memperoleh sebuah kesimpulan yang sesuai dengan inti permasalahan. Alasan SP tidak melakukan tinjauan kembali, dikarenakan ia mengaku akan mengalami kebingungan setelah apa yang ia lakukan terhadap penyelesaian tersebut, sehingga SP tidak melakukan tinjauan kembali terhadap penyelesaian yang ia lakukan pada permasalahan Nomor 1 .

Pada permasalahan Nomor 2 SP dapat memahami permasalahan pada soal tersebut dengan membaca dan mengamati gambar yang terdapat pada soal. Dari memahami soal tersebut, SP dapat menemukan inti permasalahan dari soal tersebut yaitu membantu Pak Andi mencari luas tanah yang maksimum untuk menanam tumbuhan jagung. Dengan memahami soal tersebut SP melakukan pembagian pada setiap lahan untuk membantunya mencari setiap luas tanah yang tersedia, hal tersebut dapat dilihat pada Gambar 6 dengan nomor (i). Berdasarkan uraian, SP dapat memahami dengan cara membaca soal dan melihat gambar yang tertera pada soal. SP juga dapat menemukan inti permasalahan pada soal Nomor 2 yaitu mencari lahan yang sesuai dengan Pak Andi inginkan.

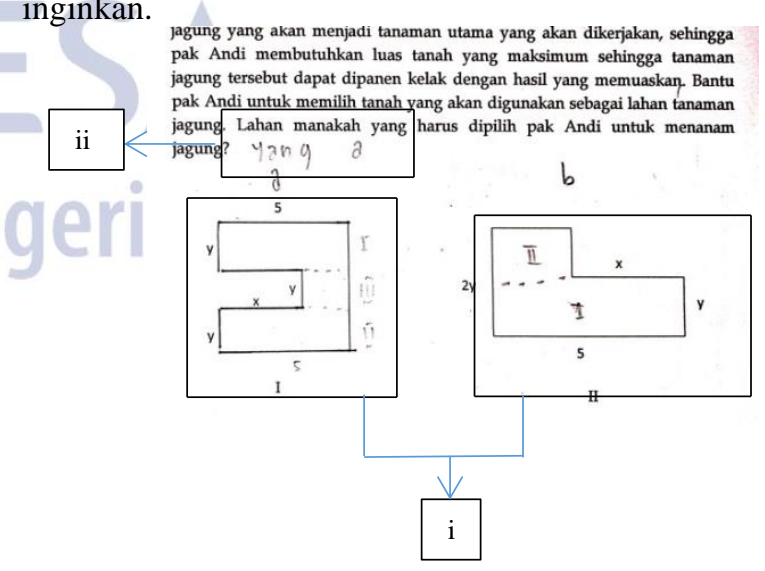

Gambar 6. Hasil Pemahaman SP pada Nomor 2

SP memilih cara menyelesaikan soal tersebut dengan mencari luas setiap bagian pada lahan yang tersedia. Ia melakukan pembagian setiap lahan untuk mempermudahnya dalam mencari luas lahan I maupun luas lahan II. Pada Gambar 6 nomor (i) SP telah menggambarkan pembagian lahan yang ada pada soal, 
dengan lahan I dibagi menjadi 3 lahan yang lebih kecil dan II dibagi menjadi 2 lahan lebih kecil. SP menjelaskan alasan yang mendukung ia menggunakan cara yang ia pilih dalam menyelesaikan soal tersebut. Alasan SP yaitu memilih cara yang sesuai dengan inti permasalahan yang ia temukan.

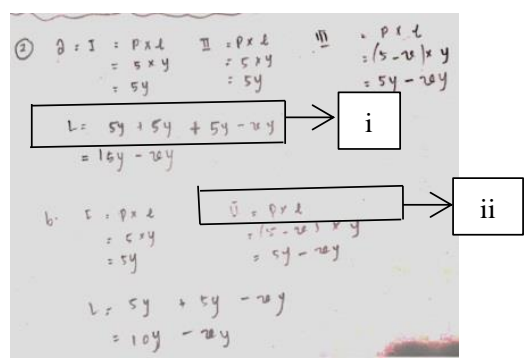

Gambar 7. Proses Penarikan Kesimpulan SP

Pada Gambar 7 menunjukan proses penarikan kesimpulan, SP melakukan langkah-langkah sesuai dengan cara yang ia pilih untuk menyelesaikan permasalahan pada soal tersebut. SP mencari luas lahan I dengan membagi 3 lahan kecil, kemudian ia mencari luas pada setiap bagian pada lahan I. Setelah itu, SP mencari luas total pada lahan I. Untuk yang lahan II, SP melakukan hal yang sama yaitu membagi menjadi 2 lahan yang lebih kecil terlebih dahulu untuk lahan II. Setelah itu, mencari masing luas pada lahan tersebut dan kemudian mencari lahan total. Setelah mencari luas setiap lahan SP dapat menarik sebuah kesimpulan yang sesuai dengan permasalahan pada soal Nomor 2, hal tersebut dapat dilihat pada Gambar 6 nomor (ii).

Pada Soal Nomor 2 SP mengungkapkan faktor penting yang mendukung ia dalam menyelesaikan permasalahan tersebut yakni, penggunaan konsep operasi hitung aljabar, luas bangun datar, serta ia melakukan pembagian setiap lahan untuk membantu mencari luas setiap lahan. Pada Gambar 6 nomor (i) mengungkapkan SP melakukan pembagian lahan menjadi lahan yang lebih kecil untuk membantu SP mencari luas, hal itu juga merupakan salah satu faktor penting yang harus dipertimbangkan. Pada Gambar 7 nomor (i) mengungkapkan bahwa SP menggunakan konsep operasi hitung aljabar, hal itu juga salah satu materi yang terkait dalam permasalahan tersebut. Untuk Gambar 7 nomor (ii) merupakan penggunaan konsep luas bangun datar yang diterapkan oleh SP untuk membantu SP menemukan solusi. Berdasarkan uraian tersebut SP dapat mengungkapkan faktor yang mendukung dalam penyelesaiannya.

Pada indikator clarity (kejelasan) SP dapat menjelesakan istilah yang ia gunakan serta dapat menjelaskan setiap langkah penyelesaian yang ia lakukan. SP menjelaskan langkah awal yang ia lakukan setelah membagi setiap kebun menjadi beberapa bagian menjadi kecil, SP mencari luas setiap bagian kecil lahan. Kemudian ia mencari luas total untuk dibandingkan luas lahan tersebut, sehingga SP dapat menemukan luas lahan yang maksimum. Dari hasil diatas, SP dapat menjelaskan istilah yang ia gunakan berkaitan dengan penyelesaiannya. SP juga dapat menjelaskan setiap langkah yang ia lakukan dalam penyelesaian tersebut.
SP tidak melakukan pemeriksaan kembali dari seluruh penyelesaian yang telah ia lakukan. Sama seperti halnya pada Nomor 1 SP juga tidak melakukan pemeriksaan kembali, ia meyakini bahwa penyelesaian yang ia tuliskan sudah sesuai dengan cara yang telah dipilih, ia juga mengungkapkan alasan yang sama pada Nomor 1. SP mengatakan tidak melakukan pemeriksaan kembali karena ia semakin bingung dengan apa yang ia tuliskan, sehingga ia tidak memeriksa kembali penyelesaian secara menyeluruh. Hal tersebut dapat disimpulkan bahwa SP tidak melakukan tinjauan kembali.

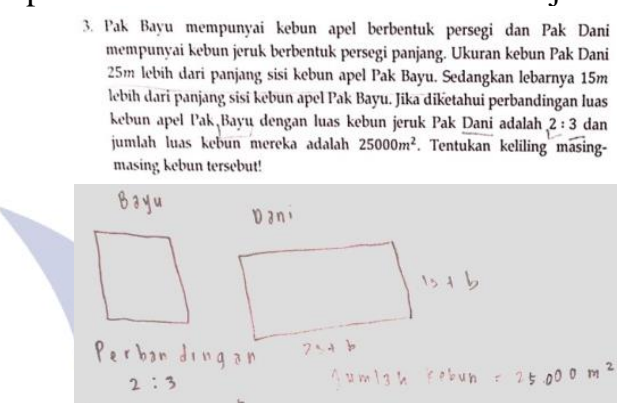

Gambar 8. Pemahaman SP pada Soal Nomor 3

Pada gambar diatas menunjukkan bahwa SP dapat memahami dan dapat menemukan inti permasalahan untuk soal Nomor 3. Inti permasalahan untuk soal Nomor 3 yakni mencari keliling kebun Pak Bayu dan Pak Dani. SP memahami soal tersebut dengan menggaris bawahi setiap kata kunci yang penting untuk membantu SP dalam mencari solusi, hal tersebut dapat dilihat pada Gambar 8 nomor (i). Gambar 8 nomor (ii) menunjukkan bahwa SP merubah permasalahan pada soal ke dalam bentuk matematis, SP menuliskan pada Gambar 8 nomor (ii) yang diketahui dan ia pahami pada soal. SP dapat memahami dengan cara menggarisbawahi informasi yang penting dan merubah ke dalam bentuk matematis. SP dapat menemukan inti permasalahan pada soal Nomor 3, dimana inti permasalahan tersebut yaitu mencari keliling kebun Pak Bayu dan Pak Dani.

Untuk alasan yang mendukung cara yang SP pilih untuk menyelesaikan soal diatas adalah lebih mudah dipahami dan lebih mudah untuk menemukan solusinya dengan menggunakan cara yang ia pilih.

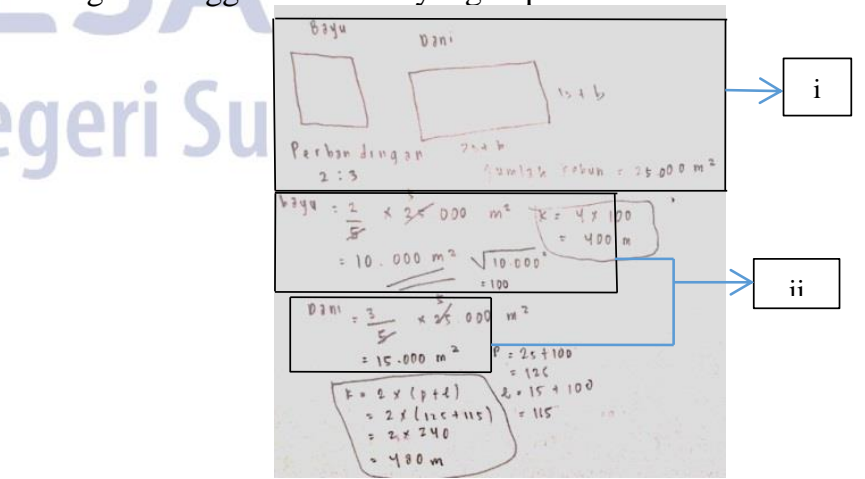

Gambar 9. Proses Penarikan Kesimpulan SP Nomor 3

Pada Gambar 9 merupakan proses SP melakukan penarikan kesimpulan dengan mengikuti langkah-langkah penyelesaian yang telah ia pilih sebelumnya. Gambar 9 nomor (i) SP menuliskan informasi yang ada pada soal, kemudian diubah ke bentuk matematisnya. Kemudian SP mencari luas kebun Pak Bayu dan Pak Dani dengan rasio 
perbandingan yang telah diketahui pada soal, hal tersebut dapat dilihat pada Gambar 9 nomor (ii). Setelah mencari ukuran lahan Pak Dani yang sesuai dengan informasi pada soal, panjang lahan Pak Dani yaitu 25 meter lebih dari ukuran panjang lahan Pak Bayu sehingga ukuran panjang lahan Pak Dani adalah 125 meter, sedangkan ukuran lebar lahan Pak Dani adalah 15 meter lebih dari ukuran panjang lahan Pak bayu sehingga ukuran lahan Pak Dani adalah 115 meter. Setelah itu, SP mencari pokok permasalahan pada soal tesebut yaitu mencari ukuran keliling kebun Pak Bayu dan Pak Dani. SP mencari ukuran keliling kebun mereka dengan menggunakan rumus keliling yang sesuai dengan bentuk kebuk Pak Bayu maupun Pak Dani, hal ini dapat dilihat pada Gambar 9 nomor (iii).

SP dapat mengungkapkan faktor penting pada Nomor 3 yaitu rasio perbandingan pada soal dapat membantu SP untuk mencari luas kebun Pak Bayu dan Pak Dani, hal ini diungkapkan SP pada Gambar 9 nomor (i). SP juga mengungkapkan bahwa materi yang berkaitan dengan permasalahan tersebut yaitu materi perbandingan, luas dan keliling bangun datar, serta operasi hitung bilangan, hal tersebut dapat dilihat pada Gambar 9 yang merupakan proses SP dalam menyelesaikan permasalahan Nomor 3. Berdasarkan uraian tersebut SP dapat mengungkapkan faktor penting yang mendukung penyelesaiannya.

Dari faktor penting yang ia ungkapkan, SP dapat menjelaskan langkah-langkah penyelesaiannya serta istilah yang ia pakai pada penyelesaian tersebut. SP menjelaskan langkah awal yang ia lakukan setelah merubah ke dalam bentuk matematis yakni mencari luas kebun masing-masing. Setelah, mencari luas kebun SP mencari panjang sisi kebun Pak Bayu dan ukuran panjang dan lebar kebun Pak Dani, kemudian ia mencari keliling kebun mereka. Dari uraian tersebut SP dapat menjeleskan setiap langkah penyelesaian yang ia lakukan. SP juga dapat menjelesakan istilah yang ia pakai pada penyelesaian tersebut. Ia mengatakan bahwa luas kebun Pak Dani yang ia cari untuk membantunya mengeecek apakah luas kebun tersebut sesuai dengan panjang dan lebar yang telah ia temukan, ia dapat menjelaskan perbandingan yang ia gunakan dalam mencari luas kebun serta panjang sisi kebun Pak Bayu.

Pada indikator overview (tijauan kembali), SP tidak melakukan pemeriksaan kembali penyelesaian yang telah ia lakukan, ia mengatakan bahwa jika ia melakukan pemerikasaan kembali maka ia akan bingung dengan langkah penyelesaian yang telah ia tuliskan, ia juga merasa bingung dengan nilai-nilai yang telah ia temukan dengan hasil operasi maupun dengan penggunaan rumus yang telah ia gunakan. SP cukup percaya bahwa penyelesaian yang ia tuliskan merupakan benar, sehingga ia tidak melakukan peninjauan kembali untuk setiap penyelesaian soal-soal tersebut.

Dari uraian diatas, kemampuan berpikir kritis SP dalam menyelesaikan soal matematika HOTS, SP dapat memahami dan menemukan setiap inti permasalahan yang ada pada soal matematika HOTS tersebut. SP dapat memberikan alasan yang mendukung ia memilih cara tersebut, ia juga dapat menarik kesimpulan dengan mengikuti setiap langkah penyelesaian yang sesuai dengan cara yang ia pilih sebelumnya. SP dapat mengungkapkan faktor penting yang ada pada setiap soal tersebut, serta ia juga dapat menjelesakan istilah pada setiap penyelesaiannya dan dapat menjelesakan langkah-langkah penyelesaian dari soal tersebut. Akan tetapi SP tidak melakukan tinjauan kembali pada setiap penyelesaian yang ia lakukan dari soal-soal tersebut. Hal tersebut sejalan dengan penelitian yang dilakukan oleh Ardani (2017) yang mengatakan bahwa siswa perempuan mampu memahami sehingga menemukan inti permasalahan, dapat memberikan alasan relevan, membuat keputusan pada argumen sehingga siswa dapat menentukan langkah penyelesaian yang mengarah pada solusi serta tidak melakukan langkah memeriksa kembali untuk mengevaluasi langkah penyelesaian yang telah dilakukan.

\section{PENUTUP \\ Simpulan}

Berdasarkan analisis hasil dan pembahasan diatas, profil kemampuan berpikir kritis siswa dalam menyelesaiakan soal matematika HOTS, siswa laki-laki dan perempuan dapat memahami permasalahan soal matematika HOTS sehingga siswa mampu menemukan inti permasalahan tersebut. Siswa dapat memberikan alasan yang mendukung siswa memilih cara yang dipilih untuk mencari solusi permasalahan yang ada pada di soal matematika HOTS. Setelah siswa dapat memberikan alasan yang mendukungnya, siswa dapat menarik kesimpulan yang sesuai dengan langkah-langkah yang telah ia pilih sebelumnya sehingga kesimpulan dapat diperoleh. Namun, siswa laki-laki tidak dapat menunjukkan faktor penting yang ada mendukung penyelesaian yang siswa lakukan, siswa juga tidak dapat menjelaskan istilah yang siswa gunakan dalam setiap langkah penyelesaian, dan siswa laki-laki tidak melakukan tahapan tinjauan kembali terhadap penyelesaian yang telah siswa lakukan. Kemampuan berpikir kritis siswa laki-laki dalam menyelesaikan soal matematika HOTS memenuhi indikator focus (fokus), reason (alasan), dan inference (menyimpulkan). Sedangkan siswa perempuan dapat menunjukkan faktor penting yang dapat mendukung penyelesaian yang siswa lakukan, dan siswa juga dapat menjelaskan istilah yang siswa gunakan dalam setiap langkah penyelesaian. Namun, siswa perempuan tidak melakukan tahapan tinjauan kembali terhadap penyelesaian yang telah siswa lakukan. Kemampuan berpikir kritis siswa perempuan dalam menyelesaikan soal matematika HOTS memenuhi indikator focus (fokus), reason (alasan), inference (menyimpulkan), situation (situasi), dan clarity (kejelasan).

\section{Saran}

Berdasarkan penelitian yang telah dilakukan oleh peneliti, peneliti mengemukakan beberapa saran sebagai berikut. Berdasarkan hasil penelitian dan kesimpulan, profil kemampuan berpikir kritis siswa dalam menyelesaikan soal matematika HOTS ditinjau dari jenis kelamin menunjukkan bahwa siswa laki-laki mampu sampai menyimpulkan sebuah permasalahan tanpa dapat memberikan alasan yang jelas dibandingkan siswa perempuan. Berdasarkan hasil tersebut, supaya kemampuan berpikir kritis siswa lebih 
maksimal sebaiknya guru dapat merancang pembelajaran yang mampu mengembangkan kemampuan berpikir kritis siswa. Bagi peneliti lain yang akan melakukan penelitian sejenis tentang proses berpikir kritis siswa ditinjau dari jenis kelamin, diharapkan dapat menggunakan lebih banyak subjek sehingga lebih lanjut mengeksplor mengenai setiap siswa yang akan dipilih serta dapat menggunakan siswa dengan memiliki kecerdasan berbeda sehingga dapat terlihat profil berpikir kritis setiap siswa yang digunakan sebagai subjek.

\section{DAFTAR PUSTAKA}

Ardani, Shinta, H., Ismail. 2017. "Profil Berpikir Kritis Siswa SMP dalam Memecahkan Masalah Matematika Ditinjau Dari Gaya Kognitif dan Jenis Kelamin". Kadima. Volume 6, No.2.

Anderson, L. \& David R. K. 2001. A taxonomy for Learning, Teaching, adn Assesing: A revision of Bloom's Taxonomy of Educational Objectives. New York: Longman.

Arend, R. (2016). Learning to Teach $\left(10^{\text {th }}\right.$ ed). New York, NY: McGraw-Hill.

Ariyana, Yoku., Ari, Pudjiastuti., dkk. 2018. Buku Pegangan Pembelajaran Berorientasi pada Keterampilan Berpikir Tingkat Tinggi. Jakarta: Kementrian Pendidikan dan Kebudayaan.

Ennis, R.H. (1996), Critical Thinking. USA:Prantice Hall, Inc.

Ennis, R.H. 2011. The Nature of Critical Thinking: An Outline of Critical Thinking Dispositions and Abilities [0nline]. Tersedia:

http://faculty.ed.uiuc.edu/rhennis/documents/Th eNatureofCriticalThinking_51711_000.pdf [04 November 2020].

Fridanianti, Avinda., dkk. 2018. "Analisis Kemampuan Berpikir Kritis Dalam Menyelesaikan Soal Aljabar Kelas VII SMP Negeri 2 Pangkah Ditinjau dari Gaya Kognitif Reflektif dan Kognitif Implusif". Aksioma. Volume 9, No.1, Hal 11-20., 1 Juli, 2018.

Kaliky, Syafruddin., Fahruh, Juhaevah. 2018. "Analisis Kemampuan Berpikir Kritis Siswa Kelas X SMA dalam Menyelesaikan Identitas Trigonometri Ditinjau dari Gender". Kadima. Volume 6, No.2, Hal 111-126., 2 Desember, 2018.

Krisagotama, Fisdianti., dkk. 2015. "Profil Berpikir Kritis Siswa Kelas VII MTs Negeri Jember 1 Filial dalam Menyelesaikan Soal Operasi Hitung Bilangan Pecahan Berdasarkan Gender". Kadima. Volume 6, No.3, Hal 77-87., Desember, 2015.
Majid, A. 2005. Perencanaan Pembelajaran. Bandung: Remaja Rosdakarya.

Nilson, Caroline, dkk. 2014. "Developing Children's Critical Thinking Through Creative Arts Exposure: An Application of Ennis's SuperSreamlined Critical Thinking Framework". Internasional Journal of Arts Education. Volume 8.

OECD. PISA 2018 Results: Combined Executive Summaries Volume I, II \& III. Paris : OECD publishing

Oesmolos, Metusalak., Novisita, Ratu. 2019. "Profil Higher Order Thinking Skill Siswa Dalam Menyelesaikan Masalah Aritmatika Sosial". Jurnal Nalar Pendidikan. Volume 7, No.1, Hal 53-60., Januari-Juni, 2019

Penyusunan, T. 2014. Buku Pedoman Penulisan Skripsi Program Sarjana Strata Satu(S-1). Surabaya: UNESA.

Permendikbud Nomor 24 Tahun 2015 Lampiran 15 tentang Kompetensi Inti dan Kompetensi Dasar Matematika SMP/MTs . 2016.

Resnick, L. 1987. Educational and Learning to Think. Washington, DC: National Academy Press.

Seals, Barbara B. \& Richey, Rita C. 1994. Teknologi Pembelajaran: Defimisi dan Kawasannya. Penerjemah Dewi S. Prawiradilaha dkk. Jakarta: Kerjasama IPTPI LPTK UNJ.

Suwarma, Dina M. 2009. Kemampuan Berpikir Kritis Matematika. Jakarta: Cakrawala Maha Karya.

Sugiyono. 2016. Metode Penelitian Pendidikan Pendekatan Kuantitatif, Kualitatis, dan RnD. Bandung: Alfabeta.

Thompson, Tony. 2008. "Mathematics teachers interpretation of higher-order-thinking in Bloom's taxonomy". IEJME. Volume 3, Number 2., July 2008.

Widana, I. W., dkk 2019. Modul Penyusunan Soal Keterampilan Berpikir Tngkat Tinggi (Higher Order Thinking Skills) Matematika. Jakarta: Direktorat Jendral Pendidikan Dasar dan Menengah Kementrian Pendidikan dan Kebudayaan.

Widoyoko, E. P. 2012. Teknik Penyusunan Instrumen Penelitian. Yogyakarta: Pustaka Pelajar. 